\title{
PENINGKATAN PARTISIPASI DAN HASIL BELAJAR SISWA DALAM PEMBELAJARAN SEJARAH DI MASA PANDEMI
}

\author{
Tiarima Marbun ${ }^{1}$ \\ ${ }^{1}$ SMA Negeri 2 Tarakan, Kalimantan Timur
}

\begin{tabular}{l}
\hline \hline Article Info \\
\hline Article history: \\
Received Jan 25, 2021 \\
Accepted April 22, 2021 \\
Published April, 2021 \\
\hline
\end{tabular}

\section{Keywords:}

online learning, google classroom, CAR, pandemic period. \begin{abstract}
This classroom action research (CAR) was conducted to increase student success in learning History with the Google Classroom (GC) application. The class as the subject is that of XI IPS-2 SMA Negeri 2 Tarakan, consisting of 36 students, with 19 male and 17 female students. They were chosen, because the class saw a very large level of online learning problems such as: students often missed class, attended late, did not do assignments, did not have data packages so they did not participate in learning, and very passive learning activities. This research was conducted in two cycles, with three meetings in each. It employed GC as the media to hold the learning process done online in the pandemic era. The results of the analysis has proved that the use of GC can help in improving student learning outcomes, based on all aspects of observation and action so that learning outcomes increase in each meeting and cycle. The learning outcomes in the first cycle showed $47.2 \%$, while in the second cycle it increased to $83.3 \%$. There were 5 students or $13.9 \%$ who had failed to reach the minimum completeness and a student was not present at the last meeting of the cycles. A remedial will be given in a separate meeting so that they can achieve the required mastery in learning. In short, learning with GC media can improve the results of learning history subject for the students in high school. Therefore, it is recommended that teachers or teachers be able to use GC in online learning.
\end{abstract}

Copyright@2021 FKIP UMP All right reserved

\section{Corresponding Author:}

Tiarima Marbun,

SMA Negeri 2 Tarakan, Kalimantan Timur

Email: marbunt28@gmail.com

\section{How to Cite:}

Marbun, T. (2021). Peningkatan Partisipasi dan Hasil Belajar Siswa Dalam Pembelajaran Sejarah di Masa Pandemi. Khazanah Pendidikan-Jurnal Ilmiah Kependidikan (JIK), 14(2), 22-31.

\section{PENDAHULUAN}

Pada awal tahun 2020 Dunia dilanda wabah Pandemi covid 19. Pandemi ini dimulai di Wuhan Cina. Dari Cina Pandemi menyebar ke seluruh Dunia yang masuk melalui pergerakan penduduk dari satu Negara ke Negara lain melalui Terminal Biss, Stasiun Kereta Api Pelabuhan Udara dan pelabuhan Laut. Indonesia merupakan salah satu Negara yang mendapat arus pergerakan Penduduk yang sangat tinggi.Pergerakan penduduk yang sangat tinggi dari dan ke Indonesia menyebabkan penyebaran Covid 19 sampai ke Indonesia. Di Indonesia pandemic mulai menyebar pada bulan Februari tahun 2020. Dengan menyebarnya Pandemi ini , maka sangat berpengaruh dalam Dunia Pendidikan. 
Sebelum Pandemi kegiatan Belajar Mengajar (KBM ) dilaksanakan di sekolah dengan pembelajaran tatap muka. Tetapi setelah pandemik menyebar sampai ke Tarakan, SMA Negeri 2 Tarakan menerapkan sistim pembelajaran daring sesuai anjuran dari Dinas Pendidikan Propinsi Kalimantan Utara. Kegiatan Tatap muka di sekolah diganti menjadi pembelajaran daring, menggunakan internet. Dalam pembelajaran tersebut, guru dipaksa harus mampu menggunakan Teknologi Informasi (IT) untuk dapat melanjutkan proses kegiatan belajar mengajarnya (KBM), menggunakan berbagai aplikasi yang ada. Mereka juga dituntut harus lebih kreatif dalam mendisain pembelajaran supaya menarik bagi siswa untuk mengikuti pembelajaran di kelas maya (virtual) (lihat Simanihuruk, 2019).

Melaksanakan KBM daring memiliki tantangan yang lebih besar. Para siswa dituntut untuk menguasai aplikasi IT dan memiliki perangkat dan paket data internet supaya dapat mengikuti kegiatan pembelajaran. Sebaliknya guru juga, selain menguasai aplikasi pembelajaran, harus menguasai berbagai metode yang lebih tepat untuk menyampaikan materi pelajaran. Hal ini agar hasil belajar siswa yang diharapkan dapat tercapai sesuai harapan.

Peneliti sebagai Guru mata pelajaran Sejarah pada SMA Negeri 2 Tarakan berusaha untuk mengembangkan diri untuk mempelajari aplikasi yang dapat di gunakan untuk melaksanakan dan memperlancar Kegiatan Belajar Mengajar di kelas. Peneliti memilih Google Classroom (selanjutnya GC) sebagai media pembelajaran untuk KBM.

Dalam pembelajaran daring tidak semua siswa aktif karena beberapa factor seperti tidak punya Handphone (HP) dan tidak punya paket data. Selain itu siswa yang punya hp dan punya fasilitas internet juga sering tidak tertib dan disiplin mengikuti pembelajaran seperti: terlambat mengisi daftar hadir , mengisi daftar hadir setelah KBM selesai, tidak menyelesaikan tugas sampai batas yang sudah ditetapkan dan nilai sebagian siswa sangat rendah.

Melihat dari kenyataan tersebut di atas, dengan kurang maksimalnya proses KBM melalui daring, maka peneliti ingin mengadakan Penelitian Tindakan Kelas di kelas XI IPS2 pada materi "Pemikiran yang melandasi Peristiwa Penting di Eropa Tahun Pembelajaran 2020/2021. Peneliti sengaja memilih kelas XI IPS-2 karena di kelas ini memiliki tingkat permasalah pembelajaran daring sangat yang besar seperti: Siswa sering tidak masuk kelas, siswa tidak mengerjakan tugas, siswa mengisi absen terlambat dan absen setelah KBM selesai, tidak memiliki paket data dan tidak aktif dalam kegiatan Pembelajaran daring.

Media pembelajaran secara umum dapat diartikan sebagai alat bantu dalam proses belajar mengajar yang dapat dipergunakan untuk merangsang pikiran, perasaan, perhatian dan kemampuan/keterampilan. Ada beberapa pendapat yang mengemukakan pendapat tentang Media Pembelajaran antara lain: Menurut Schramm (1977 dalam Rudi dan Cepi, 2008: 6), media pembelajaran adalah "teknologi yang dapat digunakan untuk keperluan pembelajaran".

Munadi (2008:7) mendefinisikan media pembelajaran sebagai "segala sesuatu yang dapat menyampaikan dan menyalurkan pesan dari sumber secara terencana sehingga tercipta lingkungan belajar yang kondusif dimana penerimanya dapat melakukan proses belajar secara efisien dan efektif'. Penjelasan ini selaras dengan pandangan Arsyad (2008), yang memandangnya sebagai alat bantu dalam proses pembelajaran baik di dalam ataupun di luar kelas. Media pembelajaran merupakan bagian dari sumber belajar atau wahana yang bermuatan intruksional untuk turut merangsang siswa dalam proses pembelajaran mereka.

Latuheru (1988), yang mengutip Santoso S. Hamidjojo, menyampaikan media pembelajaran sebagai "media yang pemanfaatannya dipadukan sesuai dengan tujuan serta isi pengajaran" dengan tujuan utama untuk mendukung kualitas proses belajar-mengajar. Lebih ringkas Smaldino dkk. (2005:9) menjelaskannya sebagai media komunikasi untuk mencapai tujuan pembelajaran. Dari berbagai paparan di atas, media pembelajaran dapat 
dimaknai sebagai alat, perangkat, atau benda apa pun, yang fungsi utamanya sebagai perangkat komunikasi yang digunakan untuk membantu keberhasilan dalam pembelajaran.

Google classroom (selanjutnya disebut GC) adalah layanan web gratis, yang dikembangkan oleh Google untuk sekolah, dengan tujuan untuk menyederhanakan membuat, mendistribusikan, dan menilai tugas tanpa harus bertatap muka. GC berfungsi merampingkan proses berbagi file antara guru dan siswa. Program perangkat lunak ini adalah aplikasi yang memungkinkan terciptanya ruang kelas di dunia maya. Selain itu, GC dapat diguanakan untuk distribusi tugas, submit tugas bahkan menilai tugas-tugas yang dikumpulkan (Herman: 2014 dalam Hammi: 2017).

Pengguna GC, sebagaimana proses penggunaan aplikasi atau program komputer yang lain, harus melakukan langkah-langkah registrasi sebelum dapat menggunakan perangkat ini. Siapa pun yang sudah biasa menggunakan telepon seluler, komputer atau pun laptop, pasti dapat dengan mudah memasang perangkat ini di gawai yang dimilikinya. Kebetulan GC sudah tersedia dalam bermacam versi, sehingga dapat dipasang di laptop/PC atau pun telepon genggam (Rangkuti, 2019).

Seperti tercermin dari namanya, GC menjadi ruang kelas virtual yang fungsinya dibuat seperti ruang kelas di dunia nyata. Sebagai perangkat lunak yang didesain oleh raksasa Internet Google, perangkat ini terintegrasi dengan aplikasi-aplikasi lain yang dimiliki oleh Google, seperti Google Drive sebagai ruang penyimpanan berbagai jenis berkas milik guru atau pun siswa. Selain itu, aplikasi lain yang lazimnya turut digunakan adalah Google Docs, Sheets, Slides untuk penyusunan berbagai macam dokumen. Guru bahkan dapat membuat berbagai kuis dengan perangkat Googleform, yang pekerjaannya secara otomatis terkumpul dalam Google Drive dari guru. Selain itu, guru juga dapat membuat tugas-tugas yang bersifat uraian dalam menu-menu GC, di mana siswa dapat menjawab melalui ruang komentar (Rangkuti, 2019).

Fleksibilitas GC memungkinkan kelas dilakukan secara real time atau pun tidak. Salah satu kendala yang timbul dalam pembelajaran daring adalah keharusan siswa untuk mengikuti materi secara langsung di tengah situasi lingkungan prasarana yang tidak merata, terutama terkait kestabilan sinyal seluler yang menjadi prasyarat interaksi daring tersebut. Akibatnya, para siswa banyak yang tidak dapat menghadiri kelas yang berlangsung. GC berpotensi menjadi solusi alternatif, karena memungkinkan pengajar atau guru menyediakan materi secara daring untuk dapat diakses dan dipelajari oleh siswa kapan pun. Selain itu, guru dapat pula mengunggah materi dalam bentuk rekaman audio/suara atau pun audiovisual/video, sehingga siswa dapat memperoleh penjelasan yang cukup gamblang mengenai materi, layaknya mereka mengikuti kelas konvensional. Bilamana pelajaran membutuhkan interaksi, guru dan siswa dapat menggunakan beberapa aplikasi lain seperti Hangout, Gmeet, atau pun Whatsapps.

Berdasarkan latar belakang tersebut diatas peneliti mengidentifikasi beberapa masalah sebaagai berikut: a) kurangnya kemampuan guru dalam mengoperasikan berbagai aplikasi pembelajaran daring, b) kurangnya kreativitas guru untuk berinovasi dalam mendisain kegiatan pembelajaran daring, c) siswa yang tidak memiliki fasilitas untuk belajar daring, d) siswa kurang aktif dalam pembelajaran daring, e) hasil Belajar siswa tidak maksimal.

\section{METODE}

Penelitian ini dilaksanakan di kelas XI IPS 2 SMA Negeri 2 Tarakan. Lokasi ini berada di Jln. Gn. Kerinci, Kelurahan Kampung Enam, Kecamatan Tarakan Timur Kota Tarakan, Kalimantan Utara, Kota Tarakan. Peneliti adalah guru yang mengajar salah satu mata pelajaran di kelas tersebut. Penelitian ini dilakukan pada semester gasal tahun pelajaran 2020/2021, berlangsung selama 3 bulan, Agustus - Oktober 2020. Periode 
tersebut bertepatan dengan jadwal mengajar peneliti, sehingga proses penelitian ini dilakukan sejalan dengan pelaksanaan kewajiban mengajar.

Subjek dalam penelitian ini adalah siswa kelas XI IPS 2 SMA . Negeri 2 Tarakan. Mereka terdiri atas 31 ( 23 perempuan dan 8 laki-laki). Kelas ini dipilih dengan melihat tingkat partisipasi siswa yang tidak maksimal dengan berbagai sebab, dan mereka gagal menguasai konsep materi dalam mata pelajaran sejarah, terbukti dari nilai yang relatif masih rendah. Dalam melaksanakan penelitian, peneliti dibantu oleh teman guru yang berperan sebagai pengamat dan kolaborator.

Rancangan penelitian ini adalah penelitian tindakan kelas (PTK) yang dilaksanakan secara daring. Tujuan penelitian tindakan ini adalah mendorong peningkatan tingkat partisipasi dan keaktifan siswa di kelas (Munadi, 2008). Dengan partisipasi dan keaktifan yang tinggi, peneliti berharap dapat meningkatkan pemahaman mereka terhadap materi yang diberikan, dan akhirnya hasil belajar mereka pun maksimal.

Penelitian ini telah dilakukan dalam dua siklus, dengan tiap siklus diimplementasikan dalam 3 pertemuan. Setiap pertemuan mengajar tersebut diwujudkan dalam 4 tahap penelitian, meliputi perencanaan (planning), pelaksanaan (action), pengamatan (observation), serta refleksi (reflection) (lihat Hidayat, 2017). Peneliti mengikuti alur penelitian tindakan kelas, seperti tergambar pada bagan berikut.

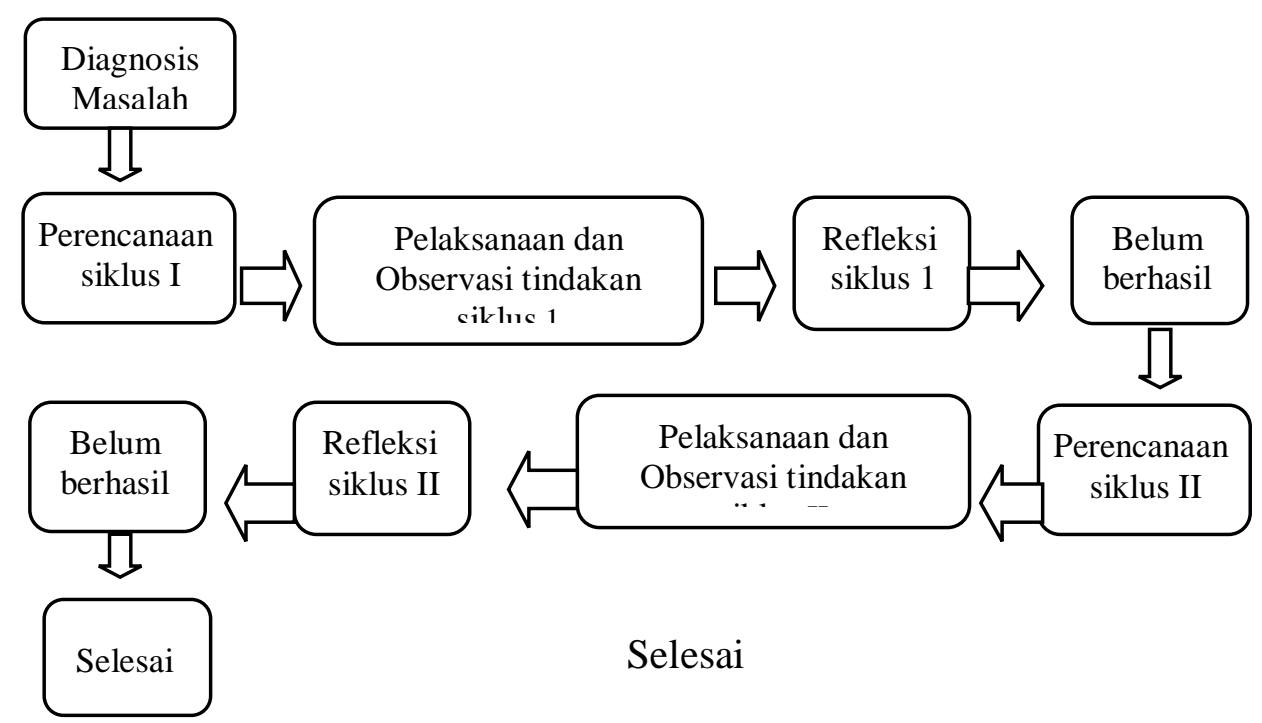

Gambar 1. Desain penelitian tindakan kelas (Hidayat, 2017)

Penjelasan alur di atas sebagai berikut.

1. Perencanaan, sebelum mengadakan penelitian peneliti menyusun rumusan masalah, tujuan dan membuat rencana tindakan, termasuk di dalamnya instrumen penelitian dan perangkat pembelajaran.

2. Pelaksanaan/Tindakan, meliputi tindakan yang dilakukan oleh peneliti sebagai upaya membangun pemahaman konsep siswa. Guru menyajikan satu pokok bahasan, kemudian diakhiri dengan pemberian test tertulis untuk mengetahui tingkat penguasaan materi siswa.

3. Pengamatan (observasi), dengan mengamati hasil atau dampak dari diterapkannya media GC. Observasi dilakukan pada tiap pertemuan, dengan perlakuan yang sama.

4. Refleksi, peneliti melakukan pencatatan-pencatatan mengenai proses pembelajaran yang diberikan. Bersama dengan guru kolaborator, peneliti mengidentifikasi kelemahan dan kekuatan dari hasil tindakan yang diterapkan di kelas. Hasil akhirnya adalah rumusan langkah perbaikan untuk tindakan berikutnya. 
Perencanaan merupakan fondasi bagi tiap siklus dan pertemuan. Tahap ini bertujukan untuk merumuskan kegiatan yang akan ditempuh untuk penerapan pelaksanaan tindakan berdasarkan keadaan pembelajaran sebenarnya di lapangan. Proses ini dilakukan bersama guru lain sebagai kolaborator. Kegiatan pada tahap perencanaan meliputi:

1. Membuat pemetaan, silabus dan Rencana Perbaikan Pembelajaran (RPP) mata pelajaran Sejarah, yang dilaksanakan secara daring.

2. Guru peneliti mendesain skenario pembelajaran dengan materi yang kemudian diunggah pada GC.

3. Mengunduh aplikasi GC untuk melaksanakan proses KBM dan mengevaluasi hasil pembelajarannya.

Pelaksanaan tindakan merupakan kegiatan pembelajaran sejarah sesuai dengan rencana pelaksaaan pembelajaran (RPP) daring. Dalam pelaksanannya, peneliti dan kolaborator dipandu oleh indikator-indikator capaian yang telah ditetapkan. Pelaksanaan tindakan ini dilakukan melalui media pembelajaran Google Classroom, sebagai ruang virtual di mana guru melaksanakan kegiatan pengajaran Sejarah untuk semua siswa.

\section{HASIL DAN PEMBAHASAN \\ a. Hasil Penelitian \\ 1) Data Awal Observasi}

\section{a) Perencanaan Awal atau Pratindakan}

Sebelum dilakukan tindakan kelas, terlebih dahulu peneliti menganalisa penyebab-penyebab apa saja yang menyebabkan rendahnya nilai rata-rata hasil belajar Sejarah kelas XI IPS 2 SMA Negeri 2 Tarakan. Salah satu tindakan yang dilakukan adalah dengan menganalisis hasil belajar yang sudah dicapai siswa sebelumnya diantaranya nilai ulangan harian semester ganjil pada saat kelas XI yang telah dilaksanakan dengan tujuan untuk mengukur ketuntasan hasil belajar siswa sebelum dilaksanakan penelitian lanjutan.

Berikut disajikan data hasil ulangan harian siswa sebelum dilaksanakan penelitian atau pratindakan, seperti tampak dalam Tabel 1. Data tersebut memperlihatkan angka ketuntasan yang sangat memperihatinkan, di bawah jauh di bawah $50 \%$. Fakta inilah yang menjadi alasan utama peneliti melakukan penelitian ini.

Tabel 1. Hasil belajar siswa pratindakan

\begin{tabular}{|c|c|c|c|}
\hline Rentang Nilai & $\mathrm{f}$ & $(\%)$ & Kriteria \\
\hline $75-100$ & 14 & 38,9 & Tuntas \\
\hline $0-74$ & 22 & 61,1 & Belum Tuntas \\
\hline
\end{tabular}

b) Analisis Hasil Pratindakan

Dikarenakan penelitian ini dilaksanakan pada masa pandemi covid-19, maka nilai yang digunakan untuk analisis adalah nilai ulangan semester genap yang sebelumnya siswa sempat melaksanakan pembelajaran secara tatap muka di kelas selama 3 bulan. Siswa mulai melakukan pembelajaran jarak jauh (PJJ) mulai pertengahan bulan maret 2020 sampai saat ini. Berdasarkan data yang diperoleh siswa pada ulangan semester genap, nilai Sejarah siswa kelas XI IPS 2 ini sangat rendah, di bawah Kriteria Ketuntasan Minimal (KKM) yang sudah di tentukan sekolah. Hanya 14 siswa $(38,9 \%)$ saja yang tuntas. Selain motivasi belajar yang kurang, siswa juga kesulitan untuk memahami pelajaran Sejarah karena semua materi hanya di bagikan dalam bentuk link dan modul. Siswa harus memahami sendiri materi yang diberikan oleh guru. Oleh karena itu, pemahaman secara 
individu harus ditindaklanjuti melalui media pembelajaran yang melibatkan guru secara langsung dalam proses penyampaian materi Sejarah.

\section{c) Refleksi pratindakan}

Berdasarkan analisis tersebut, sangat perlu dilakukan penelitian tindakan yang akan meneliti kesulitan yang dihadapi siswa, aktivitas siswa, aktivitas guru, proses pembelajaran dan keativitas dalam pembelajaran. Langkah yang diyakini dapat ditempuh adalah melalui penelitian tindakan kelas menggunakan GC dalam setiap pembelajaran. Dengan perangkat tersebut, siswa diharapkan tetap dapat belajar dari rumah dengan menggunakan telepon genggam ataupun laptop/PC yang terkoneksi dengan Internet, tanpa harus selalu daring sesuai jadwal.

\section{2) Hasil siklus I}

\section{a) Perencanaan siklus I}

Untuk melaksanakan tindakan pada siklus I, peneliti mulai menyusun Rencana Pelaksanaan Pembelajaran (RPP) daring. Disamping itu, peneliti juga mempersiapkan materi pembelajaran yang tidak ada di dalam buku paket dengan mencari dari sumber lain baik internet maupun berdasarkan pada buku-buku lain yang relevan dengan materi pembelajaran dalam bentuk modul, dan juga power point. Peneliti juga mempersiapkan presensi siswa secara daring, lembar kerja siswa (LKPD) yang akan dikerjakan siswa secara mandiri dan mempersiapkan tes akhir pembelajaran.

b) Pelaksanaan tindakan

Untuk melakukan pembelajaran sesuai dengan rencana yang telah direncanakan maka dilaksanakan penelitian siklus I (3 pertemuan) pada tanggal 8, 15, dan 22 Oktober 2020. Pembelajaran menggunakan GC dilakukan dengan langkah-langkah pembelajaran sebagai berikut.

1) Pembukaan

(a) Guru mengucapkan salam, menyapa siswa, dan meminta siswa melakukan presensi/mengisi daftar hadir pada link yang sudah dibuat guru. Siswa membalas salam, sapa, dan mengisi daftar hadir.

(b) Guru menjelaskan garis besar kegiatan dengan GC. Siswa mencermati penjelasan guru dan memberikan respon terhadap penjelasan tersebut.

(c) Guru menyampaikan apersepsi dan motivasi. Siswa memperhatikan dan memberikan respon terhadap apersepsi dan motivasi dari guru.

2) Kegiatan Inti

(a) Guru mengaitkan materi pembelajaran dan bertanya jawab dengan siswa. Siswa memberikan respon dari pertanyaan guru.

(b) Guru menyampaikan materi pembelajaran dalam bentuk media pembelajaran GC untuk penguatan literasi digital. Siswa mencermati dan menanggapi video pembelajaran yang diberikan oleh guru.

3) Penutup

(a) Guru memberikan kesempatan tanya jawab atau diskusi membahas materi pembelajaran. Siswa bertanya jawab atau berdiskusi mengenai materi pembelajaran.

(b) Guru memberikan tugas kepada siswa sebagai kegiatan pendalaman materi. Siswa mengerjakan tugas dari guru dan mengirimkan tugas ke guru melalui $G C$. 
Hasil tes akhir pembelajaran yang diperoleh dari Google Form selanjutnya dicetak. Rentangan hasil belajar siswa siklus I seperti terlihat pada Tabel 2.

Tabel 2. Peningkatan hasil belajar siswa siklus I

\begin{tabular}{|c|c|c|c|c|c|}
\hline Siklus I & f & $(\%)$ & Rerata & \multicolumn{2}{|c|}{ Tidak hadir } \\
\hline Pertemuan 1 & 17 & 47,2 & 54,2 & 6 & $16,7 \%$ \\
\hline Pertemuan 2 & 18 & 50,0 & 58,3 & 3 & $8,3 \%$ \\
\hline Pertemuan 3 & 24 & 66,7 & 68,5 & 2 & $5,6 \%$ \\
\hline
\end{tabular}

Analisis terhadap hasil belajar siswa setelah mengikuti pembelajaran siklus I pada pertemuan 3 dengan media pembelajaran pada GC maka dapat dianalisis hasil yang diperoleh sebagai berikut:

1) Siswa dengan nilai tuntas sebanyak $24(66,7 \%)$.

2) Siswa dengan ketuntasan yang masih kurang ada $10(27,8 \%)$.

3) Sebanyak 2 siswa $(5,6 \%)$ tidak hadir.

Dari pengamatan kehadiran siswa selama proses penelitian tindakan kelas, terlihat bahwa masih banyak siswa yang tidak hadir dalam pembelajaran jarak jauh sebanyak 4 orang yaitu 21,05 \%. Peneliti selalu melakukan pendekatan lagi dengan siswa yang tidak absen. Diketahui bahwa siswa atas nama MM, setelah melalui pendekatan dengan wali kelasnya dan orangtua, ternyata telah kehilangan HP, yang menyebabkan ia tidak dapat mengikuti KBM. Sedangkan siswa lainnya, atas nama RIS, terlambat bangun. Setelah pendekatan dengan orangtua melalui wali kelas, diketahui bahwa RIS merasa bosan belajar daring. Peneliti mencoba berkordinasi dengan orang tua untuk memantau kegiatan belajar anak dirumah. Peneliti dalam setiap kesempatan berupaya mengingatkan siswa untuk selalu aktif belajar. Peneliti juga selalu menyelipkan pesan motivasi agar mereka selalu semangat dan rajin belajar, menjaga kesehatan diri dan jika keluar rumah senantiasa menggunakan masker.

c) Refleksi siklus I

Berdasarkan nilai yang dicapai siswa dari pembelajaran pada siklus 1, diketahi bahwa mereka yang telah mencapai ketuntasan minimal sebanyak 24 $(66,7 \%)$, dan siswa yang belum mencapai ketuntasan minimal berjumlah 10 $(27,8 \%)$. Sisanya, 2 orang $(5,6 \%)$, tidak masuk atau absen. Artinya sejumlah 12 orang $(33,4 \%)$ dari mereka belum mampu mencapai target pembelajaran minimal. Karena itu, langkah tindakan masih harus dilanjutkan ke siklus 2, dengan 3 pertemuan.

\section{3) Hasil siklus II}

\section{a) Perencanaan siklus II}

Untuk melaksanakan tindakan pada siklus II, peneliti mulai menyusun Rencana Pelaksanaan Pembelajaran (RPP) daring. Disamping itu, peneliti juga mempersiapkan materi pembelajaran yang tidak ada di dalam buku paket dengan mencari dari sumber lain baik internet maupun berdasarkan pada buku-buku lain yang relevan dengan materi pembelajaran dalam bentuk modul, power point dan media audio visual. Peneliti juga mempersiapkan absen online siswa, lembar kerja siswa (LKS) yang akan dikerjakan siswa secara mandiri dan mempersiapkan tes akhir pembelajaran. 


\section{b) Pelaksanaan tindakan}

Untuk melakukan pembelajaran sesuai dengan rencana yang telah direncanakan maka dilaksanakan penelitian siklus II (pertemuan 4-6) pada 5, 12, dan 16 November 2020. Pembelajaran menggunakan $G C$ dengan langkahlangkah pembelajaran sebagai berikut.

1) Pembukaan

(a) Guru mengucapkan salam, menyapa siswa, dan meminta siswa melakukan presensi/mengisi daftar hadir pada link yang sudah dibuat guru. Siswa membalas salam, sapa, dan mengisi daftar hadir.

(b) Guru menjelaskan garis besar kegiatan di GC. Siswa mencermati penjelasan guru dan memberikan respon terhadap penjelasan tersebut.

(c) Guru menyampaikan apersepsi dan motivasi. Siswa memperhatikan dan memberikan respon terhadap apersepsi dan motivasi dari guru.

2) Kegiatan inti

(a) Guru mengaitkan materi pembelajaran dan bertanya jawab dengan siswa. Siswa memberikan respon terhadap penjelasan atau pertanyaan dari guru.

(b) Guru menyampaikan materi pembelajaran dalam bentuk media pembelajaran untuk penguatan literasi digital. Siswa mencermati dan menanggapi video pembelajaran yang diberikan oleh guru.

3) Penutup

(a) Guru memberikan kesempatan tanya jawab atau diskusi membahas materi pembelajaran. Siswa bertanya jawab atau berdiskusi mengenai materi pembelajaran.

(b) Guru memberikan tugas kepada siswa sebagai kegiatan pendalaman materi. Siswa mengerjakan tugas dari guru dan mengirimkan tugas ke guru melalui $G C$.

Hasil tes akhir pembelajaran yang diperoleh dari Google Form selanjutnya dicetak sebagaimana tercantum dalam Lampiran 7 Laporan ini dan rentangan hasil belajar siswa siklus II seperti tampak pada Tabel 3.

Tabel 3. Peningkatan hasil belajar siswa siklus II

\begin{tabular}{|c|c|c|c|c|c|}
\hline Siklus II & f & $(\%)$ & Rerata & \multicolumn{2}{|c|}{ Tidak hadir } \\
\hline Pertemuan 4 & 23 & 63,9 & 66,6 & 3 & $8,3 \%$ \\
\hline Pertemuan 5 & 24 & 66,7 & 70,4 & 2 & $5,6 \%$ \\
\hline Pertemuan 6 & 30 & 83,3 & 79,3 & 1 & $2,8 \%$ \\
\hline
\end{tabular}

Analisis terhadap hasil belajar siswa setelah mengikuti pembelajaran siklus II pertemuan 6 dengan media pembelajaran yang di upload pada google classroom maka dapat dianalisis hasil yang diperoleh sebagai berikut:

1) Siswa yang sudah mencapai nilai tuntas ada $30(83,3 \%)$.

2) Mereka yang belum mencapai ketuntasan minimal masih 5 siswa $(13,9 \%)$

3) Masih ada 1 siswa (2,8\%) siswa yang belum masuk kelas.

Dari pengamatan kehadiran siswa, maka dapat di lihat bahwa semua siswa aktif dalam kegiatan pembelajaran daring. Peneliti memberikan apresiasi kepada siswa karena berperan aktif dalam proses belajar, dan melalui materi yang 
disampaikan menggunakan media pembelajaran, peneliti juga selalu menyelipkan pesan untuk selalu semangat dan rajin belajar.

\section{c) Refleksi siklus II}

Seperti tampak dari nilai yang dicapai para siswa, sebanyak sebanyak 30 siswa atau 83,3\% telah berhasil mencapai ketuntasan minimal, dan 5 siswa $(13,9 \%)$ masih gagal untuk memperoleh ketuntasan minimal. Namun demikian, kalkulasi nilai rata-rata individu memperlihatkan nilai 79, 3. Artinya, penelitian sudah berhasil dan telah mencapai indikator keberhasilan. Tindakan untuk mereka yang belum mencapai ketuntasan dalam pembelajaran adalah dengan memberikan remedial dalam waktu berikutnya sehingga semua siswa tuntas dalam pembelajaran.

\section{b. Pembahasan hasil penelitian}

\section{Ketuntasan hasil belajar siswa}

Dari data yang telah dipaparkan di atas hasil penelitian menunjukkan bahwa media pembelajaran dapat meningkatkan hasil belajar siswa memberikan dampak positif. Hal ini dapat dilihat dari semakin baiknya pemahaman siswa terhadap materi Fisika yang disampaikan peneliti, yakni ketuntasan belajar meningkat dari siklus I hingga siklus II yaitu masing-masing ketuntasan pada siklus I pertemuan pertama hanya 17 orang siswa atau $47,2 \%$ saja yang tuntas dan pada siklus II pertemuan keenam meningkat menjadi 30 orang siswa atau 83,3\% tuntas secara klasikal serta nilai rata-rata siswapun meningkat dari rata-rata siklus I pertemuan pertama 54,2 meningkat pada siklus II pertemuan mengajar keenam menjadi 79,3 sehingga melampaui kriteria ketuntasan minimal (KKM) yang ditetapkan sekolah, yakni 70, walaupun masih ada 5 orang siswa atau 13,9\% belum mencapai ketuntasan minimal dan 1 orang siswa belum masuk kelas maka akan diberikan tugas remedial dalam pertemuan tersendiri dalam Google Classroom sehingga mampu mencapai ketuntasan dalam belajar.

\section{Kemampuan Peneliti Dalam Mengelola Pembelajaran}

Temuan dari analisis data memperlihatkan bahwa terjadi peningkatan hasil belajar siswa dari tiap pertemuan dalam kedua siklus tindakan yang dilaksanakan dalam penelitian ini. Hal ini tercermin dari dampak positif pada hasil belajar mereka, dengan indikator peningkatan nilai rata-rata dari siklus I, yang hanya 54,2, dan kemudian meningkat cukup signifikan setelah selesai dilaksanakan pertemuan dari siklus II, yakni nilai rata-rata kelas mencapai 79,3. Dengan demikian, dapat dikatakan bahwa penelitian tindakan kelas ini cukup berhasil untuk memecahkan masalah pembelajaran di masa pandemi.

\section{Kehadiran Siswa Dalam Pembelajaran}

Berdasarkan analisis data, diperoleh kehadiran siswa dalam proses pembelajaran Sejarah menggunakan media pembelajaran yang diunggah di GC terdapat peningkatan kehadiran siswa dalam pembelajaran. Masalah kehadiran siswa yang pada awalnya terjadi dapat di atasi oleh peneliti dengan melakukan pendekatan secara personal terhadap wali kelas dan guru BP untuk home visit ke siswa yang dianggap mengalami masalah yang lebih kompleks.

\section{KESIMPULAN}

Berdasarkan tujuan dan hasil analisis data dalam penelitian dengan judul peningkatan hasil belajar Sejarah pada materi pemikiran-pemikiran yang melandasi peristiwa-peristiwa penting di Eropa menggunakan media pembelajaran pada Aplikasi Google Classsroom dikelas XI IPS 2 SMA Negeri 2 Tarakan tahun pelajaran 2020/2021, maka dapat diambil 
kesimpulan bahwa terjadi peningkatan hasil belajar siswa pembelajaran materi pokok pemikiran-pemikiran yang melandasi peristiwa-peristiwa penting di Eropa dengan peningkatan dari $47,2 \%$ pada siklus I menjadi $83,3 \%$ pada siklus II, dengan kehadiran siswa pada siklus I hanya $83,3 \%$ meningkat menjadi $97,2 \%$ pada siklus II. Dengan memperhatikan hasil penelitian dengan ketuntasan 83,3\% dengan rata-rata nilai 79,3 maka penelitian dihentikan walaupun masih terdapat 5 siswa atau $13,9 \%$ yang belum tuntas. Untuk siswa kelompok ini, peneliti sebagai guru akan melakukan perbaikan melalui kegiatan remedial agar semua siswa tuntas dalam pembelajaran.

\section{DAFTAR PUSTAKA}

Anonym. (2017, Maret 31). Definisi Hasil Belajar Menurut Para Ahli. Retrieved from Rangkuman Pustaka: rangkumanpustaka.com

Arsyad, A. (2008). Media Pemebelajaran. Jakarta: Rajawali Pers.

Azizah, K. (2020, September 14). Apa Itu Daring, Mari Mengenal Singkatan Dua Kata ini yang Jarang Diketahui. Retrieved from Merdeka: merdeka.com

Hammi, Zedha. (2017). Implementasi Google Classroom Pada Kelas XI IPA MAN 2 Kudus. Semarang: Universitas Negeri Semarang

Hidayat, A. (2017, Febuari 3). Metodologi Penelitian. Retrieved from Statistikian: statistikian.com

Latuheru, John.D. 1988. Media Pembelajaran dalam Proses Belajar Mengajar Masa Kini. Jakarta: P2LPTK.

Munadi , Y. (2008). Sebuah Pendekatan Baru. Bandung: Jurusan Kurtekpend FIP UPI.

Pohan, A. E. (2020). Konsep Pembelajaran Daring Berbasis Pendekatan Ilmiah. Grobogan: Sarna Untung.

Rangkuti, R. U. (2019). Penggunaan Aplikasi Google Classroom Sebagai Media Pembelajaran Berbasis Blended Learning Pada Mahasiswa Teknologi Pendidikan Pascasarjana Universitas Negeri Medan (UNIMED). Prosding Seminar Nasional Fakultas Ilmu Sosial Universitas Negeri Medan, 888-893.

Rudi, S. \& Cepi, R. (2008). Media Pembelajaran. Bandung : Jurusan Kurtekpend FIP UPI.

Simanihuruk, Lidia, dkk. (2019). E-learning : Implementasi, Strategi, dan Inovasinya. Medan : Yayasan Kita Menulis.

Sharon E. Smaldino. Deborah L. Lowther. James D. Russell. 2005. Instructional Technology \& Media For Learning (Eight Edition). New Jersey : Pearson Merrill Prentice Hall Inc

\section{http://jurnalnasional.ump.ac.id/index.php/khazanah}

